Rhode Island College

Digital Commons @ RIC

2006

Statelessness and Roma Communities in the Czech Republic:

Competing Theories of State Compliance

Robyn Linde

Follow this and additional works at: https://digitalcommons.ric.edu/facultypublications

Part of the International Law Commons, and the Other Political Science Commons 


\title{
Statelessness and Roma Communities in the Czech Republic: Competing Theories of State Compliance
}

\author{
ROBYN LINDE*
}

\section{Introduction}

The system of national sovereignty, underpinning international relations in the modern world, is one wherein individuals exercise their rights and obligations primarily through citizenship in a state. Holding citizenship in a state willing to extend rights and protections is therefore the definitive factor in the exercise of rights, especially human rights. When an individual does not possess membership in any state, that individual is considered stateless. Statelessness is a problem that affects millions of people, and although the exact number of stateless people is unknown, Refugees International estimates it to exceed eleven million. ${ }^{1}$ While stateless people are found throughout the world, the largest numbers reside in the former Soviet Union, East and South Asia, especially Thailand, Nepal, Burma and Sri Lanka, as well as in Europe, the Great Lakes region of Africa, and the Middle East. ${ }^{2}$

Statelessness has multiple causes; among the most common are intentional exclusions that limit an individual's citizenship to that of his or her parents, to place of birth, or to a conflict between these alternative means of citizenship conferral. States may also revoke or refuse to grant citizenship when a marriage takes place between citizens of different states or when a state discriminates against individuals on the basis of gender, religion, political opinion or ethnicity. ${ }^{3}$ Statelessness can also occur because of administrative processes that are unnecessarily complex or because of fees that discourage individuals from applying for citizenship. Finally, statelessness can occur because of a transfer of territory following the dissolution, independence or succession of a state when long-term residents cannot obtain citizenship in the new state. ${ }^{4}$

\footnotetext{
* The author wishes to extend appreciation to the following individuals for comments made on earlier drafts: Barb Frey, Holiday Shapiro, Kathryn Sikkink, staff at the European Roma Rights Centre, anonymous reviewers, and participants of the European Roma Rights Centre Conference on Personal Documents and Threats to the Exercise of Fundamental Rights among Roma in the Former Yugoslavia (Igalo, Montenegro) in September 2002.

${ }^{1}$ M. Lynch, 'Lives on Hold: The Human Cost of Statelessness' (Refugees International, Washington D.C., 2005), p. 1.

${ }^{2}$ Ibid.

${ }^{3}$ Ibid., p. 3, E. Simperingham, 'The International Protection of Stateless Individuals: A Call for Change' (University of Auckland, 2003).

${ }^{4}$ Lynch, supra note 1, p. 5. Simperingham, supra note 3.
} 
States can protect individuals by becoming party to the treaties and declarations found in international law and by respecting their treaty obligations. Foremost among these agreements are the 1954 Convention Relating to the Status of Stateless Persons and the 1961 Convention on the Reduction of Statelessness. Under these and other treaties, states have specific obligations to refrain from creating stateless persons. States can also confer citizenship on non-nationals, thus enabling them to participate in the employment sector and national and local politics as well as have access to educational opportunities, the judiciary and healthcare systems. ${ }^{5}$

This paper examines the Czech Republic's passage in 1993 of a citizenship law that rendered approximately 10,000 to 25,000 members of the Roma community stateless. ${ }^{6}$ The Czech Republic, a former satellite state of the Soviet Union, peacefully split from the Slovak Republic with the dissolution of the Czechoslovak Federal Republic (hereafter Czechoslovakia) in 1993, a process known as the Velvet Divorce. Following the dissolution, a new citizenship law came into effect that put steep requirements on individuals who wished to gain or retain Czech citizenship. These requirements included verification of a five-year period of residence, a clean criminal record, and unwieldy fees and administrative procedures. Many argued that these requirements unfairly affected Roma, who were considered Slovakian by many nonRoma Czechs. Many Roma did not have documentation to prove citizenship or residence, had criminal records that prevented successful applications, or could not understand or afford the administrative procedures and costs required by the new law.

Following a string of previous revisions, an amendment to the law in 1999 reinstated the citizenship of the majority of these individuals. This paper examines the full spectrum of factors that led to the 1999 amendment with a special focus on the role of local nongovernmental organizations (NGOs), human rights activists, international pressure, economic policy, and the unique qualities of the post-Soviet world environment. Additionally, two major ideological trends in the Czech Republic will be presented: the 1992-1997 Civic Democratic Party (ODS) era of euroskeptism and the European Society school represented by former President Vaclav Havel and the rise of the Social Democrats (CSSD) in 1998. The Czech case is especially instructive because the citizenship law was written, enacted and revised within a period of six years. Although a number of changes took place during this time period, this paper suggests that not least of these was the accession process to join the European Union (EU) and a general trend in the Czech Republic toward participation in other international and regional institutions, including the North Atlantic Treaty Organization (NATO), the Organization for Security and Co-operation in Europe (OSCE), and the Council of Europe.

\footnotetext{
${ }^{5}$ Lynch, supra note 1, p. 3.

${ }^{6}$ Due to a number of factors including a distrust of authorities, the exact number of Roma who were affected is difficult to estimate. The number varies from the low estimate of 10,000 to 25,000 according to Human Rights Watch to 100,000 according to early estimates by the Tolerance Foundation (as reported by the European Roma Rights Commission, 'Czech Government Amends Anti-Romani Citizenship Law, but the Improvements Are Cosmetic,' review of Reviewed Item, Roma Rights, no. (1996); Human Rights Watch, 'Roma in the Czech Republic: Foreigners in Their Own Land', (1996). The earlier estimate of 100,000 appears to have been too high based on its rejection by more recent reports.
} 


\subsection{Approaches to State Compliance}

The objective of this paper is not to demonstrate the existence of compliance but to explain it. Although the 1999 amendment removed the discriminatory clauses from the 1993 citizenship law and effectively reinstated citizenship for most Roma, it is not immediately evident why the change occurred. This paper will analyse and apply two competing explanations for compliance, interest- and knowledge-based, for why the Czech Republic changed its behaviour and altered its policy. Interest-based approaches suggest that states comply with international norms when it is in their interest to do so, especially when economic gains from compliance are predicted. These theories posit that changes in state behaviour are the result of rational decision making predicated upon the individual utility of self-interested actors, the product of a cost-benefit analysis whereby states are focused on their own gains or losses. ${ }^{7}$ Within this calculus, state interests, understood as constant and unchanging, are determined exogenously to interaction with other states. Domestic politics as an explanatory variable is "negligible" in interest-based approaches and its influence delimited. ${ }^{8}$ As such, the minimal, if not absent, role of domestic politics in interestbased arguments results in the expectation that state interests would be consistent across the tenure of successive domestic actors.

Whereas an economically grounded self-interest wields explanatory power in interest-based theories, ideas and identity collectively comprise interest in knowledge-based theories. These approaches suggest that states may alter their policies through interaction with other states in the international system. Interaction with other states, ideas and institutions may affect a given state's identity regarding its role in the international sphere, which may in turn affect that state's perception of its interests, thus leading to policy change. In other words, knowledge-based theories are sociological and depart from interest-based theories in assuming a different path to compliance, one wherein identity and interest co-constitute each other. Interests, therefore, are developed within and through interaction with other states (endogenously) rather than preceding interaction with other states (exogenously). As an endogenous theory of interest-formation, these models can account for changes in interests. Moreover, endogeneity often requires theorists to examine domestic politics in order to understand the interplay of identity, interests and ideas.

Thomas Risse and Kathryn Sikkink provide a sociological model of human rights change that suggests that although states may originally alter their behaviour for instrumental reasons, they may internalize the very ideas they once rejected through socialization with other actors in the international system. This may occur in a series of phases that mark a state's path from violating human rights to compliance with human rights norms and even the institutionalization of those norms. This model recognizes the importance of economic interests but suggests that these interests may

\footnotetext{
${ }^{7}$ A. Hasenclever, P. Mayer, and V. Rittberger, Theories of International Regimes, 55, Cambridge Studies of International Relations (Cambridge University Press, Cambridge, 1997) p. 26.

${ }^{8}$ Ibid., p. 25.
} 
not always be sufficient to explain compliance. A sociological component needs to be added in order to understand fully the motivations behind compliance.

Interest-based explanations for compliance would find evidence to support their models in the greater potential economic gain of membership in European institutions over the economic loss of extending rights to thousands of indigent persons. Since interests are developed exogenously in these models, changes in leadership within a given country would not affect that country's interests. Interest-based models would be less useful if evidence suggested that compliance could not be explained without reference to ideas, values, or identity or if interests were to shift as a result of changes in domestic-level leadership. Knowledge-based approaches would expect the identity of a state to affect its likelihood of compliance, which can best be explained by these approaches if the role of ideas, shared values and identities were necessary to explain the Czech policy change. If the change in compliance by the Czech government could be explained by reference to economic interests alone, this would seriously undermine the explanatory power of knowledge-based approaches. This paper will proceed with a brief summary of international law regarding stateless persons in order to establish the norms with which the Czech Republic complied. Following this, a detailed case study will be presented regarding the citizenship law and its subsequent amendments. Finally, the case study will be analysed in the context of the observable implications of both interest- and knowledgebased approaches in order to gauge the usefulness of these approaches to explaining state compliance.

\section{Statelessness and International Human Rights Law}

The desire to ensure that all individuals possess a nationality was first expressed in the 1930 Hague Convention on Certain Questions Relating to the Conflict of Nationality Laws. ${ }^{9}$ Under the auspices of the Assembly of the League of Nations, Article 1 of this Convention stated that it is the prerogative of each state to determine its body of nationals. ${ }^{10}$ The Convention further stated, however, that this should only be respected by other states "in so far as it is consistent with international conventions, international custom, and the principles of law generally recognized with regard to nationality". ${ }^{11}$ The Hague Convention, as well as an Advisory Opinion by the 1923 Permanent Court of International Justice on the Tunis and Morocco Nationality Decrees, stressed that while it recognized state jurisdiction in determining citizenship criteria, state action was limited by the requirement that it remain within the bounds of customary law concerning nationality. ${ }^{12}$ As such, citizenship conferment or denial is a fluid concept that changes relative to international precedent.

\footnotetext{
${ }^{9}$ League of Nations, '1930 Hague Convention on Certain Questions Relating to the Conflict of Nationality Laws’ (179 League of Nations Treaty Series, 1930).

${ }^{10} \mathrm{Ibid}$.

${ }^{11}$ Ibid.

${ }^{12}$ Ibid., Permanent Court of International Justice, 'Advisory Opinion on the Tunis and Morocco Nationality Decrees' (1923).
} 
Article $15 \S 1-2$ of the 1948 Universal Declaration on Human Rights (UDHR) affirms, "[e]veryone has the right to a nationality" and "[n]o one shall be arbitrarily deprived of his nationality or denied the right to change his nationality". Nationality is understood to be a vehicle for devolution, a conduit through which rights extend from the international to the individual. In the aftermath of World War I, however, citizenship had become increasingly based on "ethnicity, language and race". ${ }^{13}$ This shift, combined with territorial transfers throughout the world, left a large number of stateless persons at the start of World War II. ${ }^{14}$ The events of the War, especially the large number of Jews left stateless following the defeat of the Axis powers, expedited the actions of international bodies in addressing the statelessness issue. ${ }^{15}$

The shortcomings of international human rights law, dependent upon the stable and competent exercise of state obligation, were first addressed by the 1951 Convention relating to the Status of Refugees (hereafter Refugee Convention). The Refugee Convention recognized that the rights of persons outside their country of origin needed to be delineated, particularly if these individuals did not possess citizenship in any state. Although the Refugee Convention extended protection to refugees, especially those who were stateless, it did not protect individuals who were stateless yet not refugees.

The 1954 Convention relating to the Status of Stateless Persons (hereafter Stateless Persons Convention) was specifically designed to protect stateless persons not covered by the Refugee Convention as stated in the Preamble. Article 1 defines a stateless person as one "who is not considered as a national by any State under the operation of its law". This type of statelessness is referred to as de jure statelessness. Commonly, an individual is de jure stateless if he or she is 'originally' or 'subsequently' stateless, that is, if he or she did not obtain nationality at birth or lost a nationality and was unable to acquire another. The 1961 Convention on the Reduction of Statelessness (hereafter Reduction Convention) strengthened the edifice of the statelessness regime by employing the same definition as the Stateless Persons Convention and reinforcing the special obligations of states to stateless individuals in the naturalization process. The Refugee Convention, Stateless Persons Convention and Reduction Convention, when considered in concert, extend protection to those individuals who cannot claim citizenship in any state, regardless of whether they are refugees. These treaties do not examine the "quality" of citizenship or the ability of a citizen to possess "effective nationality"; ${ }^{16}$ statelessness resulting from an inability either to enjoy the privileges of citizenship or to establish nationality is generally neglected by international law. This type of statelessness is referred to as de facto statelessness. A central problem of international law pertaining to

\footnotetext{
${ }^{13}$ A. M. Warnke, 'Vagabonds, Tinkers, and Travelers: Statelessness among the East European Roma,' 7:1 Indiana Journal of Global Legal Studies (1999) p. 353. C. A. Batchelor, 'Statelessness and the Problem of Resolving Nationality Status', 10 International Journal of Refugee Law no. 157 (1998) p. 239.

${ }^{14}$ Warnke, 'Vagabonds, Tinkers, and Travelers: Statelessness among the East European Roma', pp. 353-4.

${ }^{15}$ Ibid., p. 355.

${ }^{16}$ Ibid., pp. 352, 355.
} 
statelessness is that newly-formed states have not ratified the relevant treaties. ${ }^{17}$ These states are therefore only bound to customary law concerning citizenship and transfers of territory. ${ }^{18}$

Where U.N. treaties fell short in their protection, European law emerged to fill the gap. In 1997, the European Convention on Nationality opened for signature; the Convention stated that in the event of succession the state party should "take account in particular" of the "genuine and effective link of the person", his or her "habitual residence", his or her "will", and the "territorial origin" of the individual. ${ }^{19}$ Moreover, the Declaration on the Consequences of State Succession for the Nationality of Natural Persons was adopted in 1996 by the Venice Commission, a body of the Council of Europe, and posits, "the successor State shall grant its nationality to all nationals of the predecessor State residing permanently on the transferred territory". ${ }^{20}$

\section{The 1993 Czech Citizenship Law and Amendments}

This section will present the background to the passage of the 1993 Czech citizenship law and the 1999 amendment. In order to understand the motivation for the amendment and for compliance with international and regional law that the amendment represented, it is necessary to look at a number of events between 1993 and 1999, including economic policy, NGO organization and international support. Most importantly, this case study will present two major ideological trends that endured throughout the period: the trend of euroskepticism personified by Klaus and the ODS and the trend supporting European Society as advocated by Havel and later by the CSSD party.

To understand the politics of Roma statelessness, it is necessary to begin with the expulsion of the Germans from Sudetenland, in what is now the Czech Republic, following the end of World War II. Roma originating in Slovakia and Sub-Carpathian Ukraine emigrated to the region to fill the labour shortage left by the expelled Germans. ${ }^{21}$ Since almost all Czech Roma were killed in concentration camps during World War II, the overwhelming majority of Roma living in Czech territory in the decades following the war originally came from elsewhere. Human Rights Watch has estimated that "approximately 95 per cent of the Czech Republic's Roma population had moved to the Czech Republic from Slovakia after World War II". ${ }^{22}$

\footnotetext{
${ }^{17}$ J. L. Blackman, 'State Succession and Statelessness: The Emerging Right to an Effective Nationality under International Law’, 19 Michigan Journal of International Law (1997-8) p. 1142.

${ }^{18}$ See ibid. and Batchelor, 'Statelessness and the Problem of Resolving Nationality Status', for an elaboration of international and customary law regarding effective nationality.

${ }^{19}$ Council of Europe, 'European Convention on Nationality', (1997) Article 18(2).

${ }^{20}$ Venice Commission, 'Declaration on the Consequences of State Succession for the Nationality of Natural Persons', (Council of Europe, 1996) 8.a.

${ }^{21} \mathrm{~J}$. Siklova and M. Miklusakova, 'Law as an Instrument of Discrimination: Denying Citizenship to Czech Roma', 7 East European Constitutional Review (1998) p. 2.

${ }^{22}$ Human Rights Watch, supra note 6, p. 13.
} 
From 1918 to 1968, only one category of citizenship, federal citizenship, existed in Czechoslovakia. ${ }^{23}$ This changed when the state, in an effort to appease Slovak nationalists following the 1968 Prague Spring, established a second type of citizenship: Membership in the federation ${ }^{24}$ was supplemented by membership in one of the two republics. ${ }^{25}$ Membership in a republic was based on the jus soli principle (citizenship based on place of birth) for those born before 1 January 1954 and on the jus sanguinis principle (citizenship based on parental citizenship) for those born after this date. ${ }^{26}$ The use of jus soli, or citizenship as determined by place of birth, prior to 1954 meant that Roma who came to the Czech Republic shortly after World War II were not granted Czech citizenship but were instead understood to be Slovaks. The principle of jus sanguinis, or citizenship based on the nationality of one's parents, was applied to the majority of the children of these Roma, those born after 1954. Roma who emigrated to the Czech Republic after 1954 were assumed to have the citizenship of their parents, and the children, grandchildren and great grandchildren of these Roma, most of whom were born in the Czech Republic, were likewise assumed to have the citizenship of their parents. As a result of these policies, the majority of Roma within Czech territory were classified as Slovaks. Although there was an option period, during which one could change one's republican nationality, few availed themselves of this because there was no practical advantage at the time for being either Slovak or Czech. ${ }^{27}$

\subsection{The Citizenship Law}

The practical equivalency between Czech and Slovak citizenship changed in 1993 with the passage of the Czech citizenship law, Act No. 40/1993. The law effectively denied these 'Slovak' Roma, many of whom had lived within the territory now called the Czech Republic for generations, the right to vote, participate in the political sphere and take part in many areas of economic transition..$^{28}$ Although European norms and customary law would dictate that domicile residence within the territory should be an important consideration in the granting of citizenship, those with 1969 status as Slovaks were forced to undergo a complicated application process to obtain Czech citizenship. Article 18 of the citizenship law listed the requirements for seeking Czech citizenship; these included permanent and continuous residence in the territory for five years prior to the application date, proof of release from citizenship in Slovakia, and a clean record void of "wilful punishable offences" for the preceding five years. ${ }^{29}$

${ }^{23}$ Siklova and Miklusakova, supra note 21, p. 3.

${ }^{24}$ Law No. $165 / 1968$

${ }^{25}$ Law No. 39/1969

${ }^{26}$ Siklova and Miklusakova, supra note 21. There is a discrepancy in the literature regarding the date for the division of Czech citizenship between the two standards, jus soli and jus sanguinis. The Commission on the Security and Cooperation in Europe put the division at the 1968-9 law while Siklova and Miklusakova date the division to 1954. Commission on Security and Cooperation in Europe, 'Ex Post Facto Problems of the Czech Citizenship Law, Congress 104, Session No. 1', (1996) p. 2.

${ }^{27}$ Commission on Security and Cooperation in Europe, supra note 26, p. 2.

${ }^{28}$ International Helsinki Federation for Human Rights, 'Czech Republic: Annual Report 1997', (1997).

${ }^{29}$ Government of the Czech Republic, 'Act No. 40/1993 on Gaining and Losing Citizenship of the Czech Republic Dated December 29th, 1992’, (1993) Article 7 (1.c.). 
The citizenship law was passed amid a massive economic transition supported largely by Prime Minister Klaus. Klaus, along with President Havel, had previously been members of an umbrella organization called the Civic Forum that helped to bring down the communist regime in 1989 and defeated the communists in elections in 1990. The Civic Forum had its intellectual roots in a political ideology that sought unity among people and recognized the emergence of political parties as divisive. ${ }^{30}$ The organization was likewise grounded in human rights activism. ${ }^{31}$ Although the Civic Forum disbanded in 1991, many strains of this ideology endured in the form of a Havelian commitment to civil society. This political trend draws on Tocqueville and emphasizes morality and humanism, seeks a unified society and the advancement of the public good. ${ }^{32}$ As such, civil society became the "cause celebre of independent Czech intellectuals" and its cultivation was viewed as the panacea to "society's Communist-era atomisation". ${ }^{33}$ Intellectuals committed to the idea of Czech civil society also recognized the value of civil society at the regional level and aspired to membership within a larger European entity. Havel, as the most visible advocate of what can be referred to as the European society school of thought, found promise in regional and international organizations that prevent violent clashes of culture, including the EU, the International Monetary Fund, the World Bank and the United Nations, organizations whose common mission is to foster global fellowship and collective enterprise among independent states. ${ }^{34}$

With the disbanding of the Civic Forum in 1991 and the emergence of the Czech Republic's first major political party, Klaus' ODS, a challenge emerged to the "idealist" civil society approach. ${ }^{35}$ Klaus advocated political development through a party system and economic transformation based on radical privatisation and individualism. Klaus' reforms represented an abrupt departure from the concept of civil society, a phenomenon he labelled "aberrant". ${ }^{36}$ Klaus' economic plan dismissed the role of non-profit organizations in the emerging democracy and rejected any projects that were reminiscent of "social engineering". ${ }^{37}$ Where Havel and his followers wanted to develop a Third Way, a middle path between the harsh competition of capitalism and the lack of freedom under communism, Klaus wanted an economy and government that mirrored and rivalled the West. ${ }^{38}$

As Prime Minister from 1992 to 1997, Klaus initiated one of the most unregulated, free market systems anywhere in the world. Capitalizing on the population's residual fear of communism, Klaus painted his opponents as socialists and dreamers, and presented

\footnotetext{
${ }^{30}$ A. Stroehlein, 'Three Vaclavs', 1 Central Europe Review (1999).

${ }^{31}$ U.S. Department of State and Bureau of European and Eurasian Affairs, 'Background Note: Czech Republic', (2003).

${ }^{32}$ J. F. Pontuso, 'Transformation Politics: The Debate between Vaclav Havel and Vaclav Klaus on the Free Market and Civil Society', 54 Studies in East European Thought (2002) p. 156.

${ }^{33}$ Stroehlein, supra note 30.

${ }^{34}$ Pontuso, supra note 32, p. 167.

${ }^{35}$ Stroehlein, supra note 30.

${ }^{36}$ Ibid.

${ }^{37}$ Stroehlein, supra note 30.

${ }^{38}$ Stroehlein, supra note 30.
} 


\section{COMPETING THEORIES OF STATE COMPLIANCE}

his own approach as a model of economic development; he did not lack for adherents. ${ }^{39}$ Early in Klaus' term, Europe hailed the Czech Republic as a "model transition country" ${ }^{40}$ The "Czech Miracle" boasted low unemployment ( 3.5 per cent), low inflation ( 8.8 per cent), robust economic growth ( 4.1 per cent) and a 0.1 per cent budget deficit. ${ }^{41}$ Social programs, however, suffered under Klaus' economic approach as universal welfare policies gave way to means-tested policies. ${ }^{42}$

It was during this period of market-driven social welfare reform that the citizenship law was drafted and approved. Predictions of Roma emigration from Slovakia were perceived to be threatening because of the expected toll on the welfare system. A confidential document written by the Czech government in 1992 outlined the 'catastrophe scenario', the threat posed by a massive influx of 'Slovak' Roma following Czechoslovakia's dissolution. ${ }^{43}$ By most economic indicators, the Slovak Republic, and by extension those emigrating from the Slovak Republic, were markedly poorer. The Republic's gross domestic product (GDP) in 1993, at USD 13.4 billion, was less than half that of the Czech Republic, at USD 34.4 billion. ${ }^{44}$

The type of statelessness that befell 'Slovak' Roma as a result of the citizenship law can be classified as de jure..$^{45}$ Roma born in the territory of the Czech Republic enjoyed the protection of Czechoslovakia until its disintegration in 1989 and then helped to elect, in 1992, the Parliament that denaturalised them in 1993. ${ }^{46}$ Most Roma were unable to meet the requirements established in Article 18 of the citizenship law. Many lacked the necessary documents to prove residency; others resided in substandard housing due to poverty and were hence classified as 'temporary legal residents' and could not prove a five-year residency; ${ }^{47}$ still others were released from Slovak citizenship and not offered Czech citizenship. The most blatant violation of international law, especially with regard to standards of state succession, was the ex post facto penal sanction of denaturalisation for crimes committed within five years of the 1993 law. This last stipulation meant that even though the loss or denial of citizenship was not a possible penalty at the time a crime was committed, the government imposed this sanction ex post facto, thus dramatically increasing the penalties for past crimes. The applications for citizenship by Roma with criminal records were thus denied.

\footnotetext{
${ }^{39}$ Ibid.

${ }^{40}$ A. Stroehlein et al., 'The Czech Republic 1992 to 1999: From Unintentional Political Birth to Prolonged Political Crisis', 1 Central Europe Review (1999).

${ }^{41}$ Ibid.

${ }^{42}$ Ibid.

${ }^{43}$ Siklova and Miklusakova, supra note 21, p. 4. The document reportedly referred to the "Romani question" and stated that, "[w]e should use the process for the purpose of departure of not-needed persons from factories, especially for the reasons of structural changes, and for the departure of people of Roma nationality to the Slovak Republic" according to Human Rights Watch (Human Rights Watch, supra note 6).

${ }^{44}$ The World Bank Group, 'Czech Republic at a Glance', (2004) The World Bank Group, 'Slovak Republic at a Glance', (2004).

${ }^{45}$ Warnke, supra note 13 , p. 352.

${ }^{46}$ E. Schlager, 'Czech Citizenship Law Lightning Rod for International Criticism', 21 The Commissioner for Security and Cooperation in Europe Digest (1998) p. 32.

${ }^{47}$ Human Rights Watch, supra note 6.
} 
Moreover, NGOs active in the Czech Republic at the time reported that citizenship was denied to some Roma who did not have criminal records but who had been merely arrested and released without charges. ${ }^{48}$ Finally, since many Roma were not able to understand the multiple provisions of the citizenship law and because many government workers likewise did not understand the policies or deliberately misled applicants, accurate and successful applications by Roma were further discouraged.

\subsection{NGO Efforts}

Between 1993 and 1999, NGOs, activists and other norm entrepreneurs were able to draw international attention to the citizenship violations via a number of strategies. Local organizations such as HOST - Citizens Solidarity \& Tolerance Movement, the Advisory Centre for Citizenship, students of the Prague Faculty of Social Science and other activists and organizations partnered with larger Roma and human rights NGOs to establish social services and provide legal assistance to those affected by the law and to secure international support. ${ }^{49}$ These larger NGOs included Roma Civic Initiative, Helsinki Citizens' Assembly, and the Tolerance Foundation (a local Roma assistance program).$^{50}$ In 1994, a forum was established to bring these groups together in order to coordinate the dissemination of information, institutionalise codecision making, present a united front to the media and brainstorm methods of gaining international support. ${ }^{51}$

The first step of their campaign was to recognize the technical problems of 'renaturalization', including the collection of documents, and to inform victims of their rights and legal processes. ${ }^{52}$ Second, a large disjuncture developed between public and NGO support, which the coalition of NGOs tried to rectify. The disjuncture emerged when the government countered accusations of human rights violations against Roma; the public, quick to minimize the problems "of some Roma", did not therefore mobilize on the side of the NGOs and instead accepted the government's explanation. ${ }^{53}$ Governmental use of media in debunking the claims of NGOs regarding the new law was therefore effective in disabling a grassroots push for change. ${ }^{54}$ Hence, the task of developing an organizational base from which to pressure the government for change from below fell solely on the shoulders of local NGOs. ${ }^{55}$ Despite this setback, the coalition would later experience a windfall when other NGOs not focused solely on Roma issues joined their ranks. ${ }^{56}$ These other NGOs, which

\footnotetext{
${ }^{48}$ Ibid.

${ }^{49}$ Michal Horak and HOST Czech Republic, 'Brief Description of the Opposition of the Civic Initiatives against the Czech Citizenship Law (1993-1996)' paper presented at the European Roma Rights Centre Conference on Personal Documents and Threats to the Exercise of Fundamental Rights among Roma in the Former Yugoslavia, Igalo, Montenegro (September 2002).

${ }^{50}$ Ibid.

${ }^{51}$ Ibid.

${ }^{52}$ Ibid.

${ }^{53}$ Ibid.

${ }^{54}$ Ibid.

${ }^{55}$ Ibid.

${ }^{56}$ Ibid.
} 
included the Czech Branch of the Radical Party, were instrumental in winning international attention because they were experienced in media relations and some members of their boards or executives were well-known dissidents. ${ }^{57}$

\subsection{International Institutions}

Beginning in 1996, international institutions increased their criticism of the Czech Republic. The Commission on Security and Co-operation in Europe of the United States Congress (CSCE), the United Nations High Commission for Refugees (UNHCR) and Human Rights Watch joined the chorus of European criticism over the citizenship law and other issues of social justice regarding Roma. These organizations were drawn to the case by concerns over the rule of law and human rights violations. ${ }^{58}$ A 1996 UNHCR report argued that "those who were permanently resident in the Czech Republic should not, in January 1993, have been classified as Slovak citizens", that those Roma had a "genuine effective link with Czech territory", and that the "attribution of Slovak citizenship . . . does not conform with generally accepted rules of international law". ${ }^{9}$

The CSCE was especially influential early on because it focused not on the victims of the citizenship law specifically but rather on the broader issue of discrimination proscribed by customary law. ${ }^{60}$ First, the CSCE did not argue that the Czech Republic was in violation of its international obligations not to create stateless people; the argument would have been difficult to substantiate since the Czech Republic had not signed the Stateless Persons Convention and did not ratify the Reduction Convention until 2001. Instead the CSCE stressed the discrimination resulting from the differential treatment of different classes of citizens, the status of orphans, the failure to provide citizens with a fair hearing and other types of discrimination clearly within the bounds of international law already ratified by the Czech Republic. Second, the CSCE argued that the Czech Republic had an international obligation to refrain from increasing criminal penalties ex post facto. Citing legal instruments outside of the Stateless Persons Convention and the Reduction Convention, such as UDHR Article $11 \S 2$; the International Covenant on Civil and Political Rights (ICCPR) Articles 15§1, 4§2; the European Convention for the Protection of Human Rights and Fundamental Freedoms (ECHR) Articles 7§1, $15 \S 2$; and the Helsinki Final Act Principle X, the CSCE condemned what they labelled unlawful penal sanctions. ${ }^{61}$

The campaign was further bolstered by the participation of the Council of Europe. In a 1996 report, the Council of Europe ${ }^{62}$ found the ex post facto sanctions to be discriminatory in cases of state succession where the individual affected had been a

\footnotetext{
${ }^{57}$ Ibid.

${ }^{58}$ Ibid.

${ }^{59}$ Human Rights Watch, supra note 6.

${ }^{60}$ Commission on Security and Cooperation, supra note 26 , pp. 10-11

${ }^{61}$ Commission on Security and Cooperation, supra note 26, p. 10-11.

${ }^{62} \mathrm{C} / \mathrm{E} 1996$
} 
long-term resident of the state. ${ }^{63}$ The Council also took issue with the disenfranchisement of individual citizens and asserted that the criteria for citizenship should rest in a "genuine and effective link with the state concerned". ${ }^{64}$ The Council advised the Czech government to review its obligations under Article $8^{65}$ of the ECHR, which addresses private, family and home life. ${ }^{66}$

During the six years between the passage of the 1993 law and the 1999 amendment, a number of minor amendments were introduced. None, however, were able to quash the increasing international criticism of the 1993 law. The EU's early admiration for the Czech Republic, steadfast throughout the early stages of transition due to the country's economic robustness, began to show signs of wear by 1996 . The 'miracle' was seen as illusory, buttressed by corruption and overrated through arrogance. Believing that association with "lesser" countries would merely delay the Czech Republic's entry into the EU, Klaus rejected trade agreements with neighbouring Višegrad ${ }^{67}$ countries, reneging upon previous commitments to cooperate with these countries (a case in point is Klaus' foot-dragging with the European Community (EC)- "inspired" Central European Free Trade Area agreement, hereafter CEFTA) ${ }^{68}$ Some have suggested that Klaus was banking on Germany's help to enter the EU, but German Chancellor Helmut Kohl disliked Klaus both for his failure to compensate Sudeten Germans and for his critique of Kohl's "pet projects" such as the single currency. ${ }^{69}$ Klaus' arrogance regarding the Czech Republic's "exceptionalism" cost him a number of friends in Europe..$^{70}$ It was these soured relationships, along with Klaus' increasing critique of the European project that earned him a reputation of euroskepticism, one that the ODS still carries today.

By 1997, pressure from the EU and Council of Europe to amend the law as a prerequisite of accession was in full force. The Venice Convention of the Council of Europe adopted the Declaration on the Consequences of State Succession for the Nationality of Natural Persons in 1996. This Declaration, along the European Convention on Nationality, which was finalized in 1996 and opened for signature in 1997, presented clear guidelines for the conferral of citizenship in periods of state

\footnotetext{
${ }^{63} \mathrm{H}$, O’Nions, 'Bonafide or Bogus? Roma Asylum Seekers from the Czech Republic', Web Journal of Current Legal Issues (1999) section 5.

${ }^{64} \mathrm{Ibid}$.

${ }^{65}$ Article 8 of the ECHR states that "(1) Everyone has the right to respect for his private and family life, his home and his correspondence. (2) There shall be no interference by a public authority with the exercise of this right except such as is in accordance with the law and is necessary in a democratic society in the interests of national security, public safety or the economic well-being of the country, for the prevention of disorder or crime, for the protection of health or morals, or for the protection of the rights and freedoms of others."

${ }^{66}$ O’Nions, supra note 62, section 5.

${ }^{67}$ The former satellite states of the Soviet Union and Warsaw Pact signatories: Hungary, Poland, the Czech Republic and Slovakia (the latter two previously known as Czechoslovakia) are considered the Višegrad states because following the fall of the Soviet Union they agreed, in Višegrad, to work together to gain membership into NATO and the EU.

${ }^{68}$ Stroehlein et al., supra note 40.

${ }^{69}$ Ibid.

${ }^{70} \mathrm{Ibid}$.
} 
succession. States, these documents declared, are to consider domicile as well as other factors in determining nationality. ${ }^{71}$

Previous amendments to the citizenship law, dating from 1996, were "largely designed to placate international critics abroad" even though they did not bring Czech law into compliance with international norms. ${ }^{72}$ Not a single Czech political party proposed amending the more discriminatory parts of the law before 1996 and the issuance of the Council of Europe recommendations. In fact, the government ignored the criticism at first, hiding behind the mantle of state sovereignty in an effort to thwart international pressure. The impetus to amend the law substantially came only with the Czech Republic's application for EU membership in 1996, after the release of the Council of Europe recommendations in April 1996 and after the realization by the EU in 1997 that Klaus' miracle economy proved to be well short of miraculous. ${ }^{73}$

EU disapproval of Czech policy was conveyed to the Czech Republic primarily through accession documents, especially the Agenda 2000 (published in 1997) and the 'Regular Reports' that were published every year thereafter to assess the progress of the accession states toward membership. As such, "membership conditionality", the EU's carrots and sticks, incentive-based approach to inducing desired policy changes on the part of prospective member states, was used to pressure the Czech Republic to amend the citizenship law. ${ }^{74}$

This pressure was also manifested through funding from the EU for accession. The Phare program, established in 1989 to support the economic and political transition of Eastern European countries, originally focused on "sectors that contributed directly to the transition to a market economy". ${ }^{75}$ However, beginning in 1994, the program began to include support for projects with a civil society mission. ${ }^{76}$ In the years leading up to 1998, an average of EUR 100,000 was granted each year to accession countries to support projects dedicated to improving the social, economic and legal status of Roma. ${ }^{77}$ For the Czech Republic, funds were increased to EUR 0.9 million in 1998 and given directly to local NGOs. ${ }^{78}$ Between 1993 and 1999, Pharefunded programs focusing on Roma totalled EUR 2,277,600. ${ }^{79}$ Phare-funding was guided by the 1997 'Agenda 2000' and subsequent Regular Reports, which were critical of the citizenship law. ${ }^{80}$ As the Czech case demonstrates, the ability of the EU to

${ }^{71}$ The Czech Republic signed the Convention in 1999 and ratified in 2004.

${ }^{72}$ Schlager, supra note 46, p. 32.

${ }^{73}$ Siklova and Milusakova, supra note 21.

${ }^{74}$ P. Vermeersch, 'E.U. Enlargement and Minority Rights Policies in Central Europe: Explaining Policy Shifts in the Czech Republic, Hungary and Poland', 1 Journal of Ethnopolitics and Minority Issues in Europe (2003) p. 8.

${ }^{75}$ European Commission, 'Enlargement Briefing: E.U. Support for Roma Communities in Central and Eastern Europe', (1999) 3.1.

${ }^{76}$ Ibid.

${ }^{77}$ Ibid., 3.1.1

${ }^{78}$ Ibid., 3.1.2.

${ }^{79}$ Ibid., 5.2.

${ }^{80}$ Ibid., 2.3. 
persuade states to change their behaviour stems from its "political capacity", "financial resources", and the citizen initiatives it can foster. ${ }^{81}$ All told, financial leverage over the Czech Republic was considerable; from 1990 to 1997, the European Community set aside ECU 493 million for "information and research programmes, training, protection of the environment, social affairs, health, human rights and the protection of ethnic minorities, particularly Roma gypsies". ${ }^{82}$

\subsection{State Pressure}

The Czech Republic also increasingly found itself on the receiving end of international criticism from individual nations. The scrutiny increased, and the corresponding pressure intensified, in late 1997 when reportedly 'large' numbers of Roma sought asylum in Canada, the United Kingdom (U.K.) and other European countries. Canada's reaction was to criticize the Czech Republic and implement visa restrictions. To make matters worse, a series of high-profile attacks and murders of Roma and other minorities by skinheads embarrassed the country internationally and exposed a government seemingly tolerant of such violence. Between 1989 and 1997, at least 15 (and maybe as many as 29) Roma were murdered and hundreds suffered violent attacks. ${ }^{83}$ Fears began to surface that the U.K. would follow Canada's lead and implement visa restrictions for Czechs. U.K. visa restrictions were even more threatening to accession because of the negative effect they might have on the Czech Republic's application for EU membership. ${ }^{84}$ Moreover, immigration advocates in the U.K. began to argue that the violence targeting Roma might classify them as 'refugees' and thus deserving of protection under international law. ${ }^{85}$ By 1998, Roma began to win cases for asylum in both the U.K. and Canada. ${ }^{86}$

The public protests and demonstrations that followed this wave of violence offered ample opportunity for Czech politicians to commit to ending racial and ethnic division in the Republic, but they only assumed a defensive position. The government first responded by denying accusations that the citizenship law was discriminatory. An official of the Press Office of the Ministry of the Interior, Milan Kriz, argued, "[n]o such discrimination takes place in our republic" when asked about the law and its impact on Roma.$^{87}$ The Czech ambassador to the United States (U.S.), Alexandr Vondra, described the Human Rights report and Helsinki Commission report critical of the law as "lies" and denied that Roma had been made stateless. ${ }^{88}$ In 1997, the

\footnotetext{
${ }^{81}$ Vermeersch, supra note 74, p. 8.

${ }^{82}$ Economic and Social Committee of the European Commission, 'Opinion of 9 September 1998 of the Economic and Social Committee on the Czech Republic within the Framework of Enlargement and the Strengthening of the Preaccession Strategy C.E.S. 1161-1998', (European Union, 1998).

${ }^{83}$ Stroehlein et al., supra note 40.

${ }^{84}$ Ibid.

${ }^{85}$ Ibid.

${ }^{86}$ Ibid.

${ }^{87}$ Radio Praha, Roma and the Czech Republic: The Situation of the Roma in the Czech Republic in 1997, <www.romove.radio.cz/en/article/18790>, visited 25 February 2006.

${ }^{88} \mathrm{Ibid}$.
} 
Helsinki Commission published a letter to Klaus sent by U.S. Senator Alfonse D'Amato and U.S. Representative Christopher H. Smith requesting that the law be changed. Klaus replied directly, calling the letter "over-simplifying and inaccurate" ${ }^{89}$ The government responded to the UNHCR report by denying the law caused any statelessness and by issuing a document, the National Programme, which categorically denied the law's discriminatory impact on Roma. ${ }^{90}$ Even President Havel declared the law to be sound. ${ }^{91}$

In August 1997, Minister without a Portfolio Pavel Bratinka, head of the Council for Nationalities, released the Report on the Situation of the Roma Community in the Czech Republic. The government initially rejected the report, stating that its recommendations were not concrete enough. ${ }^{92}$ That same month, two rapporteurs from the Council of Europe visited the Czech Republic. ${ }^{93}$ The rapporteurs met with government officials, including Bratinka and representatives of the UNHCR, as well as with local NGOs working to amend the law. ${ }^{94}$ Their subsequent report was highly critical of Czech policy toward Roma. ${ }^{95}$

In October 1997, with the threatened visa restrictions from the U.K. looming, the Czech government did an about-face and accepted the report. ${ }^{96}$ When asked about the change, Bratinka's Deputy Minister Viktor Dobal claimed that the "ministers who had the greatest reservations about the material suddenly withdrew from their earlier comments". ${ }^{97}$ Klaus announced at a cabinet meeting that:

"the government is alarmed with the applications by some of our fellow citizens for asylum in foreign countries and is firmly determined to confront the causes which led to it. The government will do everything in its power so that no one is afraid because of their membership in this or that minority community." 98

\subsection{The Rise of the CSSD}

Between 1997 and 1998, a series of developments produced a political shake-up, resulting in a changing of the guard in the country's leadership. In November 1997, allegations of corruption in the ODS came to light, destabilizing financial markets and causing the government coalition to dissolve. Calls for Klaus to resign resounded both within and outside of his party, including a call for resignation from Havel himself. Klaus resigned that very month with the entire government following

\footnotetext{
${ }^{89}$ Ibid.

${ }^{90}$ Carol L. Kline, 'EU Inconsistencies Regarding Human Rights Treatment: Can the EU Require Czech Action as a Criterion for Accession?', 23 Boston College International and Comparative Law Review (1999) p. 49.

${ }^{91}$ Human Rights Watch, supra note 6.

${ }^{92}$ Radio Praha, supra note 86.

${ }^{93}$ D. Chirico, 'The Long, Hot Czech Summer', Roma Rights Quarterly (1997).

${ }^{94}$ Ibid.

${ }^{95}$ Ibid.

${ }^{96}$ Radio Praha, supra note 86. Government of the Czech Republic and Pavel Bratinka, 'Governmental Resolution No. 686', (1997).

${ }^{97}$ Radio Praha, supra note 86.

${ }^{98}$ Ibid.
} 
suit. ${ }^{99}$ The combination of Klaus' political fall and a recession-triggering financial crisis (characterized by a string of bank failures, revelations about the lack of competitiveness of Czech companies due to a paucity of reform, and the devaluing of the Republic's currency) brought to power the CSSD.

A force in Czech politics since the mid-1990s, the CSSD offered an alternative to the harsh market reforms and rapid privatisation of the Klaus regime. The party modelled itself after other European social democratic parties, identified with European civil society, and befriended Havel. Yet the CSSD's rise to power also coincided with a rise in euroskepticism, fuelled by trade disputes between the Czech Republic and the EU, later dubbed the 'Apple War' and 'Pork War' ${ }^{100}$ The Czech Republic had placed import quotas on EU apples, leading to the elimination by the EU of trade policies favouring the import of Czech products, including pork, poultry and juice. ${ }^{101}$ The resulting disparities in economic loss (where the EU lost 5.4 million ECU, the Czech Republic lost 23.5 million ECU) greatly increased anti-EU sentiment, which contributed in turn to the rise of nationalism. ${ }^{102}$ EU criticism of the citizenship law continued unabated, however, and in January 1998, the British Immigration Minister, Mike O'Brien, singled out the Czech policy regarding Roma during a visit to the Republic. The public critique "stung" the government, which only then indicated a willingness to address the situation. ${ }^{103}$

When elections took place in June 1998, the optimism of the early 1990s had turned cynical; few even expected that EU accession would lift the national mood. ${ }^{104}$ Although the CSSD had won 74 of 200 seats, up from 61 in the 1994 elections, its modest gain meant that it could not rule alone. ${ }^{105}$ An 'opposition agreement' between the CSSD and the ODS was reached, securing for the CSSD a minority government, while the chairmanship of both houses was given to the ODS. ${ }^{106}$ Milos Zemen of the CSSD became Prime Minister and created a new government position for the protection of human rights. Petr Uhl, a Charter 77 signatory, received the appointment. Charter 77, an association of dissidents in Czechoslovakia that organized to draw attention to violations by the Soviet regime during the late 1970s and 1980s, was founded on Western notions of human rights, particularly those laid out in the UDHR and the Helsinki Final Act. ${ }^{107}$ Uhl was thus not only familiar with international standards of human rights; he understood the persuasive power of international pressure 40 .

${ }^{99}$ Due to regional support, however, Klaus remained the ODS leader. See Stroehlein et al., supra note

${ }^{100} \mathrm{Ibid}$.

${ }^{101}$ Ibid.

${ }^{102}$ Ibid.

103 'Constitutional Watch', 8:1-2 East European Constitutional Review (1998).

${ }^{104}$ Stroehlein et al., supra note 40.

${ }^{105}$ European Parliament, 'Briefing No 4, the Czech Republic and the Enlargement of the European Union', (2000) p. 8.

${ }^{106}$ Stroehlein et al., supra note 40.

${ }^{107}$ D. C. Thomas, 'The Helsinki Accords and Political Change in Eastern Europe', in T. Risse, S. C. Ropp, and K. Sikkink (ed.), The Power of Human Rights: International Norms and Domestic Change (Cambridge University Press, Cambridge, 1999) pp. 223-4. 
and the means of leveraging it. Zemen also began tackling older EU projects such as Višegrad cooperation in CEFTA and regional restructuring.

The effect of the economic unravelling on the position of European institutions toward the Czech Republic was readily apparent. In the Agenda 2000, the Commission's opinion on Czech membership in the EU, the Commission assumed a critical stance, stating that the ex post facto penal sanction "was inconsistent with the rule that state succession cannot result in people who have lived continuously in the territory becoming aliens or stateless persons". ${ }^{108}$ The Agenda went on to conclude, however, that the 1996 amendment served to mitigate the effects of the unlawful sanctions. ${ }^{109}$ More pointed criticism from the European Commission would not be voiced until after the Czech economy began to decline precipitously. The Council of Europe's European Commission against Racism and Intolerance (ECRI) and the Economic and Social Committee of the European Union released reports that were highly critical of the citizenship law in March and September 1998, respectively. ${ }^{110}$ In November 1998, the European Commission ratcheted up its critique as well, issuing a pointedly negative report on the readiness of the Czech Republic for EU membership. ${ }^{11}$ The citizenship law ranked high on its list of issues. This document, the first yearly progress report on the Czech Republic, took aim not only at the law but its intended remedy in announcing that the 1996 amendment which was drafted to redress the problem of unlawful penal sanctions "has not had much effect". ${ }^{112}$ The report stated, "[b]ureaucratic obstacles, administrative fees and the lack of a concerted approach by the relevant Ministries have delayed a successful resolution to the problem". ${ }^{113}$ The Commission then expressed hope that the CSSD government would "offer an effective solution" by passing a more substantive amendment "so that all former Czechoslovak citizens residing in the Czech Republic at the time of the dissolution of the Czechoslovak federation and who are still living there now may acquire Czech citizenship". ${ }^{114}$

The shift in opinion of the Czech Republic by European institutions was mirrored within the Republic as well, as opinion polls revealed steadily decreasing levels of support for accession as a result of the trade disputes and the country's recession. By January 1999, Czech polls showed support for EU membership at an all-time low of 57 per cent, down from 85 per cent in 1993 and 72 per cent in 1998. ${ }^{115}$ The European

\footnotetext{
${ }^{108}$ European Commission, 'Agenda 2000-Commission Opinion on the Czech Republic's Application for Membership in the European Union, Doc/97/17' (1997) p. 14.

${ }^{109}$ Ibid.

${ }^{110}$ Economic and Social Committee, supra note 81. European Commission against Racism and Intolerance, 'E.C.R.I. General Policy Recommendation No. 3: Combatting Racism and Intolerance against Roma/Gypsies' (Council of Europe, Strasbourg, 1998).

${ }^{111}$ European Commission, '1998 Regular Report: From the Commission on Czech Republic's Progress Towards Accession’ (1998).

${ }^{112}$ Ibid., p. 10.

${ }^{113}$ Ibid.

${ }^{114}$ Ibid.

${ }^{115}$ European Parliament, 'Briefing No 41, Public Opinion on Enlargement in the E.U. Member States and Applicant Countries' (1999).
} 
Parliament indicated the drop might be in response to the import disputes of the apple and pork 'wars'. ${ }^{116}$

Although all parties voiced some reservations regarding EU entry in order to tap into the growing anti-EU sentiment and an increasingly nationalistic political climate, the CSSD and Havel acted to strengthen ties with Europe despite the furor over the trade disputes. ${ }^{117}$ The CSSD had been careful to cultivate a commitment to European society, despite fears that increased competition could harm labour and other areas of society that served as the party's political base. The CSSD identified with the European project and supported accession primarily because it was committed to social programs developed by other social democratic and labour parties in Europe and to the ideas embodied in the European Social Charter. ${ }^{118}$ Havel, in typical European society fashion, had expressed a desire for "European civic belonging", recognizing the advantages of membership within a "super-state community", including "indivisible" security and a common constitution. ${ }^{119}$ Moreover, Havel had routinely criticized the ODS for its domestic and international policies, including a timely call in 1997 denouncing "Czech provincialism, selfishness, and isolationism in politics". ${ }^{120}$

After a change in leadership, and despite the opposition of the ODS, the Czech Senate approved an amendment to the citizenship law in July $1999 .{ }^{121}$ The amendment declared that those individuals who resided on Czech territory on 31 December 1992 were eligible for Czech citizenship. Havel signed the amendment in August 1999, making the Czech Republic compliant with norms regarding statelessness. In 2004, the Czech Republic joined nine other states in gaining EU membership.

\section{Findings}

Interest-based approaches would predict that the eventual compliance of the Czech Republic with international norms and law did not reflect a change in preferences over outcomes, only a change in preferences over policies. Thus, these theories would dictate that the Czech Republic's preference of economic gain remained constant; only a change in strategy occurred. The expected influx of large numbers of Roma was predicted to cause economic loss, leading to the passage of the 1993 citizenship law; conversely, economic gain was predicted with admission to the EU, and the subsequent amendments to the law were efforts to secure membership. Interest-based approaches would suggest that the change in compliance in 1999 was

\footnotetext{
${ }^{116}$ Ibid.

${ }^{117}$ A. Stroehlein, 'Let Sleeping Euro-Dogs Lie', 0:25 Central Europe Review (1999).

${ }^{118}$ L.A. Rovna, 'The Enlargement of the European Union: The Case of the Czech Republic', 2:1 Perspectives on European Politics and Society (2001) p. 16.

${ }^{119}$ European Parliament, supra note 104, p. 17.

${ }^{120}$ M. Potucek, 'Havel Versus Klaus: Public Policy Making in the Czech Republic', Journal of Comparative Policy Analysis: Research and Practice (1999) p. 166.

${ }^{121}$ European Roma Rights Centre, 'Czech Republic Amends Anti-Romani Law', 3 Roma Rights Quarterly (1999).
} 
entirely based upon the perceived economic advantages of EU membership, and could be explained without reference to ideas such as euroskepticism and European society. Furthermore, because interests are developed exogenously prior to interaction, these approaches assume that it is not necessary to explore changes in domestic leadership as an explanation for the state's shift in compliance.

Such an explanation might go as follows: the Czech Republic has long had a material interest in gaining access to European markets. Therefore, when international organizations, especially European organizations, began to pressure the state to conform to human rights standards, it complied in an effort to gain access to European markets and admission into European institutions, notably the EU and Council of Europe. Especially applicable here is Beth Simmons' argument regarding the International Monetary Fund. According to Simmons, interest-based approaches suggest that reputation plays a role in state compliance with international law. ${ }^{122}$ In particular, Simmons found that reputational concerns are most acute within regions. According to Simmons, states make commitments to win credibility within a particular issue-area. They commit when it is in their interest to do so, and they comply in order to enhance their reputation. Simmons argues that states that expect economic gains in the long run will comply even in the face of substantial short-term losses. Regional commitments play a role in part because countries that lag behind their neighbours, especially when their markets are practically interchangeable, face competitive disadvantage. ${ }^{123}$

The Czech Republic did see neighbouring countries as competitors, especially those, like the Višegrad states, with similar economies. Under the Klaus regime, the ODS did not cooperate fully with the EC's CEFTA agreement because cooperation with these countries was perceived to negatively effect its prospects for EU admission. An interest-based theorist would suggest that since the Czech Republic saw itself competing with neighbouring countries for EU membership, it acquiesced to EU demands, including the 1999 amendment, in order to remain competitive for accession.

This account raises two questions: first, since the Czech Republic expressed interest in joining the EU shortly after the fall of the Soviet Union, why for six years did it flout international standards regarding citizenship conferral following the transfer of territory? If the promises of economic gain in EU accession were the sole motivator behind the passage of the 1999 amendment, why did these promises exercise so little impact prior to 1999 ? One possible explanation is that the human rights violations of the original citizenship law were poorly understood until they were clarified by domestic NGOs. Similarly, another explanation is that Klaus and the ODS did not grasp the extent of the EU and the Council of Europe's concern with the law. If this were the case, it follows that substantive amendments would have been made at an earlier stage, soon after the Council of Europe expressed disapproval in 1996 and the EU issued its own condemnation of the law.

\footnotetext{
${ }^{122}$ B. A. Simmons, 'International Law and State Behavior: Commitment and Compliance in International Monetary Affairs', 94:4 American Political Science Review (2000).

${ }^{123} \mathrm{Ibid}$.
} 
Moreover, the first task of domestic NGOs was to delineate the exact nature and effect of the law on Roma, which they did shortly after the law's passage. If the law's supporters claimed ignorance over its impact on Roma and Europe's consequent reaction, they could not easily do so after 1996. More importantly, Klaus and many members of the ODS were steadfast in their support of the law and their opposition to any substantive amendments even as late as 1999. It is therefore difficult to maintain that uncertainty over the law's human rights violations or Europe's reaction was cause for the ODS' ongoing support given that this support did not wane even after the amendment became a priority for accession.

Second, why did the Czech Republic pass the amendment when Eurobarometers showed the lowest support for accession since 1989 and when trade disputes had increased anti-EU sentiment to such a degree that it became politically advantageous for parties to express reservation? Why did the Czech Republic comply with EU demands in the face of a deep recession and the increasingly inequitable costs of compliance? These questions can only be answered by examining the basis of support for the original citizenship law and the 1999 amendment. As presented in the case study above, Klaus' ODS party was responsible for the economic restructuring that led to the 1993 citizenship law. ${ }^{124}$ Furthermore, although minor amendments were introduced during Klaus' tenure as Prime Minister, a substantive amendment was not passed until after Klaus had resigned and the CSSD took power. A euroskeptic ODS passed the citizenship law and voted against the 1999 amendment. The ODS did not reverse course and comply with European human rights norms because it was privy to more information and thus recognized the long-term economic potential of EU membership; rather, the ODS continued to vote just as it had in 1993. The CSSD, on the other hand, passed the amendment when the country's economic interests suggested a different policy approach. This is consistent with the CSSD position that EU accession would not merely be an economic integration but a political and social one as well.

The case provides evidence of both the usefulness and the incompleteness of interest-based approaches in important ways. While it may be true that economic interests were the principal motivator behind the ODS' support for the 1993 law and its opposition to the 1999 amendment, the amendment's ultimate passage speaks to the presence of competing motivators. A more complete explanation for the Czech Republic's compliance with European human rights norms lies in the Havelian vision of the Czech Republic as a European state and its identity with the European community. The CSSD secured the amendment's passage despite an economic relationship marked by large-scale inequality, massive short-term losses, and widespread public disdain. Interest-based theories are unable to explain fully the amendment's passage unless they are broadened to include the role of identity and the values and ideas of individuals in domestic politics, particularly ideas in support of European society. As such, they do not explain how interests are developed, and are not fully capable of explaining policy change.

\footnotetext{
${ }^{124}$ Some social benefits, such as maternity leave, were increased under Klaus. See Stroehlein et al., supra note 40 .
} 
A knowledge-based approach to the 1999 amendment might go as follows: The Czech Republic was a country undergoing fundamental change in the first part of the 1990s. During this time there were competing ideological schools of thought: one, represented by Klaus and the ODS, was a school of euroskepticism whose inconstant vision of the Czech Republic vacillated between a market economy modelled upon the West to the more reactionary nationalism that followed the trade disputes. This was the party that flouted EU policy both in passing the citizenship law and in opposing the 1999 amendment. A second school of thought, embodied by Havel and later by the CSSD, was a European society school that sought membership in a European civil society that shared its values and ideology. The CSSD's rise to power was the decisive factor in the amendment's passage.

Knowledge-based theories would suggest that in order to understand the Czech Republic's compliance in 1999 with international standards of citizenship conferral in periods of territory transfer it is necessary to look at the ideas of domestic agents along with their vulnerability to international pressure. ${ }^{125}$ There was virtually no substantive government attention to amending the citizenship law until after the Council of Europe, UNHCR and CSCE recommendations in 1996. One study conducted by Peter Vermeersch found that policy documents pertaining to Roma were "direct responses to monitoring by the Commission and by other monitoring agencies on which the EU has relied". ${ }^{126}$

Certain knowledge-based theories, however, suggest that rationality is important in understanding state behaviour. These approaches hold that interest-based theories play an important explanatory role but one that is incomplete. The pro-European CSSD embraced the idea of an inclusive European society and sought membership within it. The effort by the CSSD to mute international criticism and comply with international norms can partially be explained by an economic interest in membership in the communities that were most vociferously critical of the Czech Republic. Interest-based theories, however, expect states to behave in ways that maximize their long-term economic benefits. Therefore, states should overlook short-term losses but only when it is clear that these losses are indeed short-term. When the economic forecast is cloudy or when new priorities emerge, interest-based theories cannot explain why states stay the course in the face of possible long-term economic losses.

\footnotetext{
${ }^{125}$ Some knowledge-based theories, such as some forms of constructivism, stress the importance of domestic politics or actors in shaping policy. Although bottom-up models are drawn from theories of liberalism, knowledge-based approaches such as liberal constructivism and other actor-centred models differ from liberalism in three important ways: First, domestic actors, even those influenced by international politics, may not be powerful enough to institute change in their country. Liberal constructivists promote an alternative model that explains how these actors win international support to foster change at home. Second, liberal constructivism offers a theory for how states link up transnationally with other organizations and groups of individuals that share its goals. Finally, these organizations employ different tactics such as developing a "common frame of meaning" in order to shape the terms of the debate and persuade other actors of their position. See M. E. Keck and K. Sikkink, Activists Beyond Borders (Cornell University Press, Ithaca, 1998) p. 8 for more information about liberal constructivism and the activities of NGOs attempting to change state policy.

${ }^{126}$ Vermeersch, supra note 73, p. 22.
} 
In other words, if it was clear to policymakers in the Czech Republic (both in the ODS and the CSSD) that short-term economic losses were a necessary hurdle to the long-term economic gain that EU membership promised, then interest-based theories sufficiently explain the adoption of the amendment by the CSSD (but not its rejection by the ODS). If, as the case demonstrates, vocal members of the public were increasingly pessimistic about the advantages to be secured through EU membership, then interest-based theories need an added dimension to fully explain why some policymakers continued to actively pursue membership and embrace policies that ran counter to the country's economic interests. Regardless of which interpretation one finds more credible, there is a puzzle: If the former interpretation is accepted, then the ODS should have supported the 1999 amendment that would result in short-term economic losses but long-term economic gain; they did not. If the latter interpretation is accepted, as this paper argues, what motivated the CSSD to pursue a pro-European policy in the face of uncertain gains? Interest-based theories cannot explain the adoption of the amendment without reference to the ideas and values of domestic agents, namely the pro-European Society school of thought represented by the CSSD.

Risse and Sikkink's model is useful because it lays out a clear pattern of state behaviour regarding human rights change, a spiral pattern according to which states reject, deny, accept and change their policies to comply with international and regional pressure. ${ }^{127}$ This model draws on a type of knowledge-based approach, labelled 'strategic social constructivism', which recognizes the utility of interestbased approaches but sees these approaches, in certain cases, as insufficient or incomplete. In Table 1, the Czech case is plotted in order to present actual changes in compliance in relation to the expectations of the model.

Beginning with phase 1 , the citizenship law rendered approximately 10,000 to 25,000 individuals stateless in 1993 and led to the mobilization of local NGOs around the issue. Met with resistance and the denial of human rights violations by the government, NGOs sought and received international support. The government reacted to the increased attention, both internationally and domestically, by denying the validity of the accusations and citing its sovereignty as a means of dispelling the criticism (phase 2). The government made tactical concessions in the form of a variety of minor amendments between 1996 and 1999 (phase 3); however, it was not until a change in domestic leadership that the more discriminatory parts of the law were amended (phase 4). One could argue that phase 5, rule-consistent behaviour, was accomplished by the Czech Republic's entry into the EU in 2004.

Interest-based theories are most useful prior to phase 1 and during phase 3 of Risse and Sikkink's spiral model (see Figure 1). Klaus supported the law in 1993 because the ODS-led government was concerned about the immigration of Slovak Roma, a potential obstacle to economic reform. The tactical concessions of phase 3 coincided with the demise of Klaus' miracle economy. It was only when Klaus could

${ }^{127}$ T. Risse, S. C. Ropp, and K. Sikkink (eds.), The Power of Human Rights: International Norms and Domestic Change, Cambridge Studies in International Relations (Cambridge University Press, Cambridge, 1999) pp. 17-35. 
Table 1. Spiral Model of Human Rights Change as Applied to the 1993 Citizenship Law in the Czech Republic.

\section{Expectations \\ of Risse and \\ Sikkink's \\ Model}

Phase 1:

Repression

The Model as Applied to the Citizenship

Law in the Czech Republic

Phase 2:

1994-1997 The ODS government denies accusations of human

Denial rights violations. In its denial, it cites national sovereignty and, among other tactics, launches a media campaign to combat the charges by domestic and international organizations.

Phase 3:

1996-1999 The ODS government makes some concessions

Tactical

Concession

Phase 4: 1999

Prescriptive

Status

Phase 5:

2004

Rule-consistent

Behaviour. allowing for amendments to the citizenship law but the most discriminatory parts of the law remain intact. The criticism of the Czech government by NGOs increases. Important international actors such as the CSCE, UNHCR and the Council of Europe apply pressure to the government. Negotiations for accession are formally launched with the European Union in December of 1997.

Klaus and the ODS resign in 1997. The CSSD comes to power and passes the 1999 amendment.

The EU invites the Czech Republic to join in December 2002. The Czech Republic joins the EU in 2004. Rule-consistent behaviour is expected by accession into a community like the EU that requires transparency and possesses enforcement mechanisms.

no longer stand on his economic record that he turned his attention to other EU demands. Sociological approaches begin to work in phase 3 . What began as instrumental changes in rhetoric increasingly became "a true dialogue over specific human rights allegations" leading to the compliance of phase $4 .{ }^{128}$

${ }^{128}$ Ibid., p. 28. 


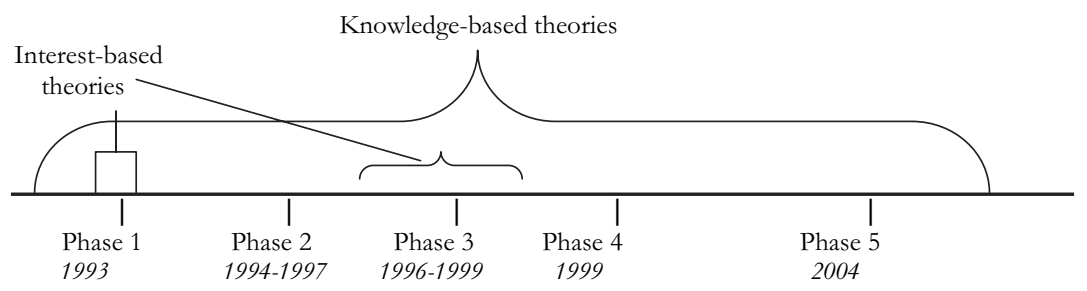

Figure 1. Knowledge- and Interest-based Theories as Applied to Phases of the Spiral Model

The CSSD was more vulnerable to criticism over the citizenship law, which explains the relatively quick move toward compliance between the elections in June 1998 and the passage of the amendment in July 1999. A change in leadership in 1998 thus led to compliance because the CSSD possessed different ideas about global civil society than did the ODS. The European-minded CSSD was vulnerable to domestic and international (especially European) pressure because it sought membership in a community on the basis of shared values. This type of vulnerability to pressure occurs when particular elements of the international community exercise leverage over the violating state. The degree to which a state wishes to join a particular community is determinative in its decision to comply with the norms and rules of that community. Amy Gurowitz, in a study of Korean and migrant worker rights in Japan, found that changes in discriminatory policies in Japan have been a result of domestic actors employing international norms as leverage against a resistant state. ${ }^{129}$ Gurowitz found that this leverage, however, is dependent upon the state's vulnerability to international criticism, especially in areas which the state perceives as important to its identity or to the way in which it functions in the international system. ${ }^{130}$ The CSSD, unlike the ODS, was vulnerable to international pressure because the idea of a greater Europe was foundational to its ideology and political platform; the CSSD and the 'civil society intellectuals' were willing to ride out the unfair tariffs, crushing economic reforms and often unrealistic social and economic requirements because they already perceived themselves as members of the larger European community.

\section{Conclusion}

As the discussion demonstrates, interest-based arguments are useful but insufficient to explain the Czech Republic's compliance with European human rights norms in amending its 1993 citizenship law. The Czech Republic's compliance with these norms must be primarily attributed not only to economics, but also to identity, to the

${ }^{129}$ A. Gurowitz, 'Mobilizing International Norms: Domestic Actors, Immigrants, and the Japanese State', 51:3 World Politics (1999) p. 415.

${ }^{130}$ Ibid., p. 445. 
Havelian identification of the Czech Republic as a European state, and by extension, to an acceptance of European standards as Czech standards. A central tenet of interest-based theories is that interests are exogenous and hence, unchanging. Thus, when a change in interests is evident, as in this case study, interest-based theories cannot fully account for that change. Instead, a complementary approach is called for, whereby interest-based theories are made complete by sociological theories, which emphasize the role of ideational agents in producing change and securing compliance with human rights norms.

Unlike interest-based theories that assume a universal rationality across time and space, knowledge-based theories recognize the role of the post-Soviet world environment and the influence of this environment on the ability of actors to comply or in the compulsion to conform.

As Risse and Sikkink make clear, it is not economic advantage alone that allows a state to resist or comply; the most vulnerable states are often the ones with the greatest concern for reputation, specifically a reputation that conforms to their selfidentity. ${ }^{131}$ The CSSD would not have been as vulnerable to regional and international pressure had it been faced with this policy decision in a different period of time. The emerging market economy, the transition from Soviet rule, and the lure of European society are all historically contingent. In order to understand fully the renaturalization of Roma in the Czech Republic, it is necessary to examine both the interests of actors and the identities through which interests emerge.

${ }^{131}$ Risse et al., supra note 126 , p. 8. 